\title{
Implementation of Cycle Learning Based on Dayak Kenyah Uma'lasan Culture in North Kalimantan
}

\author{
Kadek Dewi Wahyuni Andari ${ }^{1}$, Samriati $^{2}$, Suyadi $^{3}$, Agustinus Toding Bua ${ }^{4}$
}

\author{
1,2,3,4 Faculty of Teacher Training and Education, Borneo Tarakan University, Tarakan, Indonesia \\ Corresponding Author*E-mail: kadekdewi1985@gmail.com
}

\begin{abstract}
This research's aim is to determine the implementation of Learning Cycle based on culture and to observe the learning outcomes of students in terms of three aspects (affective, psychomotor, and cognitive) at SDN 002 West Tanjung Palas. The focus of this research is the application of learning (Learning Cycle) in elementary schools based on the Dayak Kenyah cultural dance Uma'Lasan medeq ubeq-meceq utat in North Kalimantan. The approach and type of this research is descriptive qualitative. This research was conducted at SDN 002 West Tanjung Palas. The informants in this study were 3 students (with high, medium, and low abilities), teacher, and tribe leader. Research data collection techniques are interviews, observation, and documentation. The data analysis technique of this research is data reduction, data presentation, and conclusion drawing. The validity technique in this research is technical triangulation, data sources, and time triangulation. Based on the results of the research, The dimension of learning implementation (Learning Cycle) based on culture (dance meceq ubeq - meceq utat) on the material of sound energy, students are able to follow learning using this model students are more active in class. The second dimension is learning outcomes in terms of three aspects (cognitive, affective, and psychomotor). Students are able to solve description questions, are able to practice sound energy based on the Dayak culture dance, yet there are students with low abilities who have difficulty to solve the questions correctly.
\end{abstract}

Keywords: learning cycle, science learning based on cultural dance

\section{INTRODUCTION}

Culture has values that are always passed on, interpreted and implemented, along with changes in social processes. Culture is the work of humans who can develop their attitudes towards life and are passed on from one generation to the next through communication and learning processes so that the inherited generation has a strong character in running life .

Local wisdom is a view of life and knowledge as well as various life strategies in the form of activities carried out by local people that answer various problems in fulfilling their needs[1]. According to Rahyono in the article human intelligence is owned by a certain ethnic group through community experiences. Anthropological scientists like
Koentjaraningrat and friends categorize human culture which has become a forum for local wisdom to ideas, social activities, artifacts. Therefore, Indonesia is known as the largest archipelago in the world. Kalimantan Island is one of the largest islands in Indonesia. Kalimantan Island has five provinces consisting of South Kalimantan, West Kalimantan, Central Kalimantan, East Kalimantan and North Kalimantan. Dayak Kenyah are the largest sub-tribe of Dayak in North Kalimantan. The Dayak Kenyah are not only one, but are further divided into several sub-tribes, including Dayak Kenyah Uma'Lasan, Lepo 'Tepu, Lepo'Tau, Lepo'Ma'ut', Lepo Uma'Kulit, and many more Dayak Kenyah other tribes. Lepo Uma'Lasan is one of the Dayak Kenyah sub-tribes on the island of Borneo. In this research, the researcher 
leads to the socio-cultural work of the Dayak Kenyah Uma'Lasan 'dance, which refers to the traditional dance art.

Dance is a traditional work starting from the legacy of the ancestors, which is passed down from generation to generation of society. Dayak Kenyah Uma'Lasan have many dances, including DatunJulut, Gong Dance, Men's Singles / Doubles Dance and others, which are often performed in traditional ceremonies. Apropriate to this thing, The researchers are interested in researching the traditional dance of the Kenyan Dayak tribe Uma'Lasan which is often performed in harvest festival ceremonies, namely, Meceq Utat, Meceq Ubek. Because the dance contains a lot of cultural values of the Dayak Kenyah Uma'Lasan tribe in Long Sam village. When associated with the Science Learning Analysis with the dance of the Dayak Kenyah Uma'Lasan cultural tribe, namely the easy mash of glutinous rice (meceq ubeq), this dance is related to the Natural Science material about Energy. In the Big Indonesian Dictionary (KBBI) energy is the ability to do work (for example for electrical energy, mechanics) power and strength can be used to carry out various activity processes. The sticky rice mash dance (meceq utat), first the people of Long Sam village take or harvest young glutinous rice, the term is the paddy that has not been too yellow get harvested.

The energy produced from the beginning of the process of making the glutinous rice mash dance is sound energy, motion energy, human energy and changes in the shape of objects, but researchers are more focused on sound energy. This MeceqUbek Meceq Utat dance has become a tradition of the Dayak tribe of Long Sam Village in celebrating the Harvest (Damai Ajau) party, this dance uses the traditional mash tools of the local Dayak tribe (Lesung danAluh), traditional Dayak Kenyah Uma'Lasan tribal clothing, and is accompanied by Sampe and Gongs.

Based on this, the researchers are interested in researching the local wisdom of the Dayak Kenyah Uma'Lasan culture by learning science, because there has never been any previous research that focused on the Dayak Kenyah Uma'Lasan sub-tribe. From the results of observations, many Dayak Kenyah Uma'Lasan cultures must be tought and preserved by future generations of the Dayak Kenyah Uma'Lasan in certain Meceq Ubeq and MeceqUtat dances associated with Energy material in grade IV Elementary School. Therefore, researchers need to conduct research on the Local Wisdom of the Dayak Kenyah Uma'Lasan community in the Panen Festival (Harvest Festival) traditional ceremony through the title "Application of Science Learning in Schools Based on Dayak Kenyah Uma'Lasan Cultural Dance, MeceqUbek, Meceq Utat in North Kalimantan". Based on the explanation given above, The formulations of the problem in this study are:

1) how to apply the implementation of science learning (Learning Cycle) based on the Dayak Kenyah Uma'Lasan culture?,

2) How is the description of student outcomes after the implementation of the application of science learning (Learning Cycle) based on Dayak Kenyah culture?

The purposes of this research are: 1) To know the description of the application of science learning (Learning Cycle) based on Dayak Kenyah culture, 2) To determine the description of student's learning outcomes after the application of science learning (Learning Cycle) based on DayakKenyah culture.

\section{METHOD}

The approach and type of research used in this research is descriptive qualitative. According to Moleong's opinion qualitative research is research that uses open interviews to examine and understand the attitudes, views, feelings, and behavior of an individual or a group of people[2]. Meanwhile, qualitative methods are called traditional methods, because this method is used long enough so that it is easy to tradition as a method for research. This method is called positivistic because it is based on the philosophy of positivism. This method is a scientific method / scientific, because it meets scientific principles, namely concrete / empirical, objective, measurable, rational, and systematic [3]. This study is intended to obtain information and descriptions of the application of science learning based on the cultural dance of the Dayak kenya. Uma'Lasan Meceq UbeqMeceq Utat in North Kalimantan. There are two focuses in this research. This focus refers to the formulation of the problem. In the research focus 
there is a research dimension. The focus and dimensions of this study are as follows: 1) Application of Culture-Based Learning Cycle a. Stage, Introduction b. Exploration Stage, c. Explanation Stage, d. Elaboration Stage, e. Evaluation Stage. 2) Learning outcomes in terms of three aspects (cognitive, affective, psychomotor): a. Cognitive Domain, b. Affective Domain, c. Psychomotor Aspects

The researcher chose the research location on $\mathrm{Jl}$.
Sekolahan RT 03 Long Sam Village, West Tanjung Palas District, Bulungan Regency, North Kalimantan Province. The research time was carried out on February 20, 2018 until March 20, 2018.The informants in this study were two teachers, three students (with high, medium, low abilities), one tribe leader. Informants in this study are those who are able to provide information to researchers, following Table 2.1 , is the researcher informant table.

Table 2.1 Informant Researcher

\begin{tabular}{ccc}
\hline Position & Koding & Sex \\
\hline Class Teacher & ML & F \\
Art Teacher & AB & F \\
Tribe Leader & SU & M \\
Student & JR & M \\
Student & RR & M \\
Student & SSA & M \\
\hline
\end{tabular}

The research instrument is the tool to measure which Qualitative research instruments are conducted by researchers themselves. Data collection techniques in this study, researchers used observation / interview observations, and documentation. Data analysis techniques in this study, researchers used a model according to Miles and Huberman which consists of three activities, namely data reduction, data presentation (data display), drawing conclusions (verification). The data validity technique in this study, the researcher used tringulation as a data validity technique. Tringulation is defined as a data collection technique that combines various data collection techniques and existing data sources [4], [5]. When the researcher collects data by tringulation, then the researcher actually collects data which also tests the credibility of the data, namely checking the credibility of the data with various data collection techniques and various data sources while time triangulation is to re-check interview data, observations or other techniques in a different time or situation. different repeatedly so that data certainty or saturation is found. This research used technique triangulation, method triangulation, source triangulation, and time triangulation [6].

\section{RESULTS AND DISCUSSION}

1. Application of Culture-Based Learning Science (Learning Cycle)

This culture-based science learning is made really about the local culture that is not foreign to teachers, students and society. According to [7] Natural Sciences (IPA) is a group of knowledge, has special characteristics, namely studying natural phenomena that are factual (factual), either in the form of reality (reality) or events (event) and the relationship of cause and effect. So by linking implementing this multicultural learning, science learning here we invite students to learn factual, real and events related to science [8], [9]. Before carrying out learning, we as teachers must prepare a lesson plan, class IV science material, second semester, the time allocation is $2 \times 35$ minutes with competency standards for understanding various forms of energy and how to use them in everyday life, the basic competencies are describing heat energy, sound energy that exists in the natural environment and its properties, the indicators that will be obtained after the following learning consist of three domains, which are cognitive, affective, psychomotor, after this learning is done, the objectives that will be obtained by students after this learning is done, namely: 1 ) Comparing the 
propagation of sound in solid, liquid, and gas objects, 2) Identifying that sound can reflected or absorbed, this learning is carried out using the Learning Cycle learning model, the media used are aluh, mortar, rice. When conducting interviews, teachers at SDN 002 Tanjung Palas Barat rarely or never use models during learning and teaching activities, thus making students less active in participating in lessons at school. With the application of science learning in this culturebased elementary school it will make students more active, creative and get to know their own culture through learning.

This learning is deliberately carried out in rural areas in order to make students more familiar with and have extensive knowledge about the culture both outside and in learning. What teachers in rural areas had never done before was to improve student learning outcomes. With the application of science learning in this culture-based elementary school, it will make students more active, creative and get to know their own culture through learning. Next is the learning implementation plan. The sequence of learning the Learning Cycle based on its phase and in the first dimension will be described as follows:

\section{a. Preliminary stage}

This stage is the initial activity or the preliminary stage in the application of science

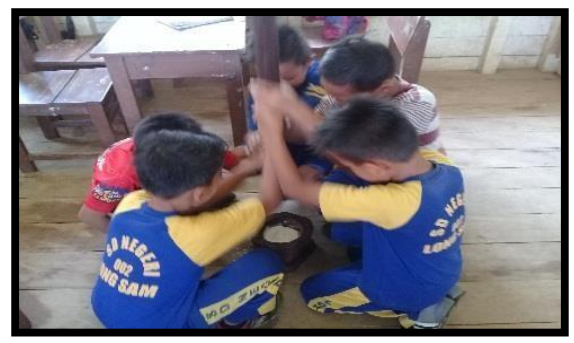

learning at SDN 002 West Tanjung Palas based on Dayak Kenyah Uma'Lasan culture, at this stage the teacher conditions and prepares everything needed in learning, the teacher greets students, the teacher invites students to pray together, the teacher asks the students' condition, motivates and shows selfreadiness by filling in the attendance sheet of students, conditioning students to receive lessons. Based on the explanation from the teacher and fourth grade educators, that in applying the learning cycle model of the first stage the teacher first asks several questions to explore the thinking skills of students, then provides motivation so that the enthusiasm to accept the lesson is good. This stage is to provoke the emotions of students before receiving the lesson.

\section{b. Exploration Stage}

At this stage students are involved in learning activities, to see the activeness and creativity of students, form students in heterogeneous groups and provide student worksheets, so that discussions occur in groups, here students are given opportunities to work with groups. This stage is carried out to see whether the science material associated with the culture becomes an example of practicum in learning.

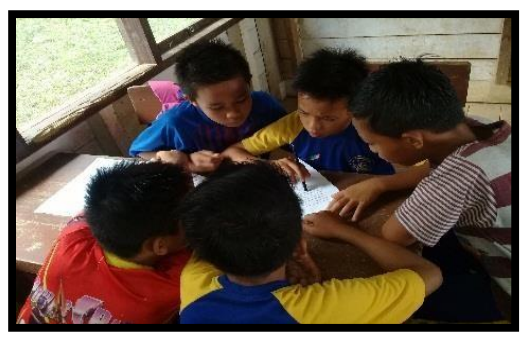

Figure 1. Students Learning Activities

\section{c. Stage Explanation}

At this stage we can see students moving forward to deliver the results of their discussions and prove the results of the practicum. After students complete their practicum assignments, here each group in turn will be responsible for the results of the practicum by explaining the results of the discussion in front of the class. 


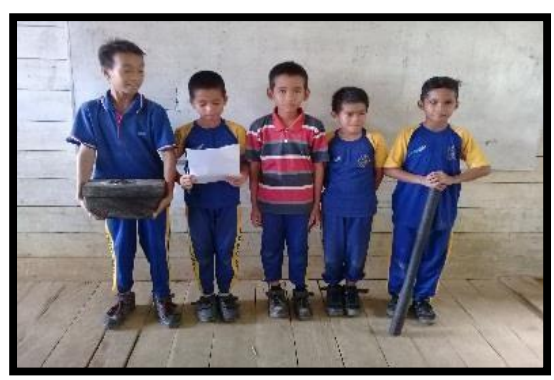

Figure 2. The Discussion in front of the Class

\section{d. The elaboration stage}

At this stage students are asked to deepen knowledge about a theory, by familiarizing students read, write and test hypotheses, then conclude together. To find out this, the teacher provides a description test to support the affective and psychomotor domains.

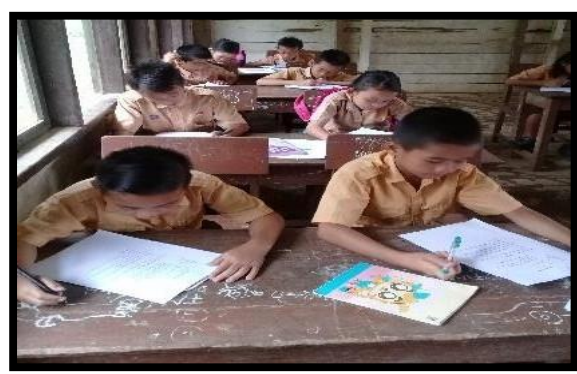

Figure 3. Elaboration Stage

It can be concluded that at this learning stage, the material was delivered and was given a test to test the knowledge skills of students regarding science material related to culture. has delivered.
At this stage students are given feedback by asking several questions, this feedback is done to find out to what extent the material taught can be mastered. Feedback is very important for students and teachers.

\section{e. Evaluation Stage}

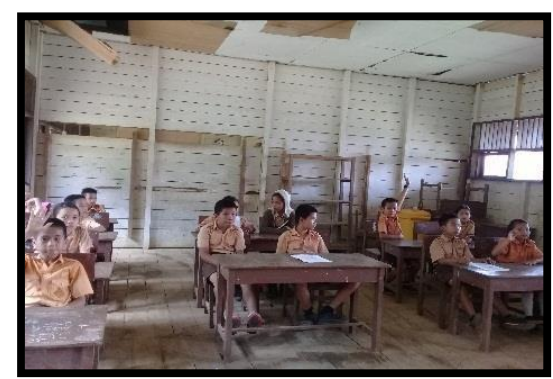

Figure 4. Evaluation Stage

2. Learning Outcomes in View of Three Aspects (Affective, Cognitive, Psychomotor)

According to Bloom in [4] learning outcomes, namely cognitive, affective, psychomotor, learning is often defined as patterns of actions, values, definitions and attitudes, as well as perceptions and 
abilities. To achieve these learning objectives, a teacher must be able to facilitate students properly and professionally [2], [10]. Researchers' observations regarding student learning outcomes can be seen from documentation, observation, and interviews of informants who have been selected by researchers [11]. The reason is that researchers can find out that the culture-based science material presented by the teacher has met competency standards.

\section{a. Affective Aspects}

Affective domains are those related to attitudes, values, emotions, and the degree of acceptance or rejection of an object in teaching and learning activities [9], [12]. Based on the results of observations of students regarding the affective learning outcomes, the attainment assessed by the researcher in the attitudes of the aspects ranging from: 1) discipline, indicators of arriving on time that there is one student who is late, indicators of following learning that students do not play in class, indicators of discipline during learning that students obey the rules in the class, the indicator of being able to complete the task is one student who does not complete the task on time [13]. 2) cooperation, on indicators of being able to find materials for students to prepare practicum materials, on indicators of being able to find answers together with students being able to work together with their groups, on indicators of being able to carry out group discussions students can complete the task together, the indicators come to find solutions here, students are directly involved [14]. 3) responsibility, the indicators participate in completing the given task that students play a role in completing it, the indicators are able to avoid cheating students do not cheat, on the indicators of doing what has been said without being asked or taught, students are able to complete the assigned task, on indicators perform individual tasks well that learners are able to complete tasks such as homework, or other individual tasks [15].

\section{b. Psychomotor Aspects}

This area includes competence to do work by involving limbs and competences related to physical (motor) movement which consists of reflex movements of basic movement skills, perceptual abilities, accuracy, complex skills, as well as expressive and interactive [6], [16]. In the matter of sound energy, the aspects of skills assessed by students are: 1) Conducting experiments on sound energy with the achievement indicator assessed is the ability to practice sound energy here students are directly involved, indicators of the ability to experiment with energy sources of students are directly involved in carrying out practical experiments. 2) Experiment with propagation, reflection, and damping. The indicator of the ability that is assessed is doing the propagation experiment here, the indicator of the ability to carry out the experiment of sound propagation, the indicator of the ability to reduce the sound of students who are directly involved in every practicum. 3) The next skill aspect is to take responsibility. The indicator that is assessed for ability is to ask confidently, here students convey their opinions well. Indicators of the ability to ask questions without stuttering the curiosity of high students. Indicators of the ability to argue or protest against errors that appear that students are able to convey their opinions. Indicators of the ability to answer confidently that students are able to convey their opinions well. Indicators of the ability to answer broadly that students are able to convey their opinions well [4].

\section{c. Cognitive Aspects}

Based on the results found by researchers through interviews, observation and documentation, a temporary conclusion can be drawn that in the dimensions of the application of science learning in culture-based elementary schools, where the application of learning is carried out using the Learning Cycle learning model which is carried out systematically, namely the preliminary stage, the exploration stage, the explanation stage, the elaboration stage, the evaluation stage [6], [17]. In the first dimension, the application of culture-based science learning at the preliminary stage is supported by statements of students (JR, RR, and SSA) and supported by statements from class IV teachers (ML). Furthermore, in the second dimension, there are learning outcomes that will be achieved in terms of 3 domains, namely, the affective domain, the psychomotor domain, the cognitive domain after the application of this learning is carried out in the fourth grade science material about Sound Energy, then 
associated with the Dayak Kenyah Uma'Lasan cultural dance.

\section{CONCLUSION}

1. Application of science learning in elementary schools

\section{a. Introductory stage}

This preliminary stage where the teacher and students start learning together by praying, delivering motivation, giving questions and answers to activate the students' interest in following the lesson.

\section{b. Exploration Stage}

At this stage students will be involved in learning, and here the role of the teacher will facilitate students. Here students are asked to be more active and creative. During the practicum, each group prepared tools and materials (mortar and aluh) so that students put in the rice and formed a circle to do the meceq ubeq, meceq utat dances. From this dance we will listen to sound energy such as sound propagation, sound attenuation, sound reflection. While doing practicum, each group will complete the assigned task.

\section{c. Explanation Stage}

Furthermore, at this stage students will explain the results of the discussion in front, and other groups will provide responses to the results of groups that have explained the results of the discussion.

\section{d. Elaboration Stage}

Likewise at this stage the teacher provides description questions to determine cognitive abilities through the basic competencies of students during learning.

\section{e. Evaluation Phase}

The last stage is that the teacher provides feedback in the form of questions to find out to what extent what has been taught can be mastered.

2. Learning Outcomes in View of Three Aspects (Affective, Psychomotor, Cognitive).

\section{a. Affective Domain}

During the lesson, the fourth grade students of SDN 002 Tanjung Palas Barat have followed the lesson well.

\section{b. Psychomotor domain}

In this realm we can see how students are actively involved in participating in learning.

\section{c. Cognitive Domain}

The cognitive abilities of students that the researcher got through three students, namely JR, RR, and SSA. That each of them has a good ability in completing the assigned task even though there are some students who are less able to complete it.

Based on the explanation above, it can be concluded that in implementing learning we must know what basic competency needs will be achieved in learning, from there we can plan a good lesson to fulfill these competencies.

\section{REFERENCES}

[1] D. N. L. Laksana and F. Wawe, "Penggunaan Media Berbasis Budaya Lokal Dalam Pembelajaran Ipa Untuk Meningkatkan Aktivitas Belajar Dan Pemahaman Konsep Ipa Siswa Sekolah Dasar," J. Ilm. Pendidik. Citra Bakti, 2015, doi: 0000-0003-4695-5403.

[2] M. Yunus, K. Dewi, W. Andari, M. A. Islam, J. Pendidikan Guru, and S. Dasar, "The Principal's Competences in Implementing Cultural and Environmental Management Of The School In SDN 033 Tarakan," $J$. Pendidik. Indones., vol. 6, no. 2, pp. 263-273, 2017, doi: 10.23887/jpi-undiksha.v6i2.11982.

[3] R. S. Retno and W. L. Yuhanna, "Implementasi green living berbasis scientific inquiry pada pembelajaran ipa terhadap kinerja ilmiah mahasiswa," Prem. Educ. J. Pendidik. Dasar dan Pembelajaran, vol. 8, no. 1, 2018, doi: 10.25273/pe.v8i1.2087.

[4] I. G. A. I. Purnamaningsih, D. K. N. Semara Putra, and I. W. Wiarta, "Learning Cycle Model Assisted Audio Visual Increase Science Knowledge Competence," Int. J. Elem. Educ., vol. 4, no. 3, p. 291, 2020, doi: 10.23887/ijee.v4i3.25877.

[5] J. T. Ningsih et al., "PENGARUH MODEL STUDENT TEAMS-ACHIEVEMENT DIVISIONS （ STAD ) BERBANTUAN MEDIA MIND MAPPING TERHADAP KEMAMPUAN BERPIKIR KRITIS SISWA SEKOLAH DASAR Effect of Model Student Teams-Achievement Divisions ( STAD ) Aided Media Mind Mapping to Critical Thinking Abi," vol. 2, no. 2, pp. 107-119, 
2020.

[6] R. Efendi, E. Emzir, and A. Rahmat, "The Improvement of Students' Ability to Write Exposition Text through Learning Cycle Model," JETL (Journal Educ. Teach. Learn., vol. 3, no. 2, 2018, doi: 10.26737/jetl.v3i2.751.

[7] I. M. A. Winangun, "Media Berbasis Budaya Lokal dalam Pembelajaran IPA SD," Edukasi J. Pendidik. Dasar, vol. 1, no. 1, pp. 65-72, 2020, [Online]. Available: https://stahnmpukuturan.ac.id/jurnal/index.php /edukasi/article/view/529.

[8] M. Özenç, H. Dursun, and S. Şahin, "The effect of activities developed with web 2.0 tools based on the 5e learning cycle model on the multiplication achievement of 4th graders," Particip. Educ. Res., vol. 7, no. 3, 2020, doi: 10.17275/per.20.37.7.3.

[9] A. Imran, R. Amini, and A. Aliasar, "The development of Science learning module use the Learning Cycle 5E for Elementary School student," in Proceedings of the International Conference on Education, Social Sciences and Humanities - ICESSHum 2019, 2020, pp. 122126, doi: 10.32698/hum0206.

[10] H. Syofyan and T. L. Amir, "Penerapan Literasi Sains dalam Pembelajaran IPA untuk Calon Guru SD,” J. Pendidik. Dasar, 2019.

[11] K. Khan, W. Aurangzeb, and T. Tahir, "Effectiveness of 5 Es Learning Cycle Model on Students Learning in Physics at Secondary School Level in Pakistan," Glob. Soc. Sci. Rev., vol. V, no. I, 2020, doi: 10.31703/gssr.2020(v-i).48.
[12] K. Dewi, W. Andari, D. Alrinda, and N. Febriani, "KETERAMPILAN LITERASI SAINS SISWA SEKOLAH DASAR The Effect Of Scientific Learning on Elementary School Students ' Literacy Skills," vol. 2, no. 2, pp. 101-112, 2020.

[13] A. Cahyarini, S. Rahayu, and Y. Yahmin, "The effect of 5E learning cycle instructional model using socioscientific issues (SSI) learning context on students' critical thinking," J. Pendidik. IPA Indones., vol. 5, no. 2, 2016, doi: 10.15294/jpii.v5i2.7683.

[14] R. Marfilinda, R. Rossa, J. Jendriadi, and S. Apfani, "The Effect of 7E Learning Cycle Model toward Students' Learning Outcome of Basic Science Concept," J. Teach. Learn. Elem. Educ., vol. 3, no. 1, 2020, doi: 10.33578/jtlee.v3i1.7826.

[15] A. Kurniawati and A. Mawardini, "Implementasi Pembelajaran berbasis Pemanfaatan Lingkungan Sekitar untuk Meningkatkan Aktivitas Belajar IPA SD," Indones. J. Prim. Educ., vol. 1, no. 2, p. 39, 2017, doi: 10.17509/ijpe.v1i2.9314.

[16] M. I. Faizin and E. H. Wasis, "Development Of Contextual Teaching And Learning (CTL) Learning Instruments With Predict, Observe, Explain (POE) Strategy To Training Critical Thinking Skills," Int. J. Sci. Res. Publ., vol. 9, no. 9, p. p93107, 2019, doi: 10.29322/ijsrp.9.09.2019.p93107.

[17] A. Imran, R. Amini, and A. Aliasar, "The development of Science learning module use the Learning Cycle 5E for Elementary School student," vol. 3, pp. 122-126, 2020, doi: 10.32698/hum0206. 